\title{
Correction to: Bone mineral density in elite masters athletes: the effect of body composition and long-term exercise
}

\author{
Anna Kopiczko', Jakub Grzegorz Adamczyk², Karol Gryko ${ }^{3 *}$ and Marek Popowczak ${ }^{4}$
}

Correction to: Eur Rev Aging Phys Act 18, 7 (2021)

https://doi.org/10.1186/s11556-021-00262-0

Following the publication of the original article [1] the authors noticed that Tables 4 and 5 in some place dots are missing; therefore, some values are not true.

The original article [1] has been updated.

The correct Tables 4 and 5 are shown below.

Table 4 Multiple backward stepwise logistic regression in male masters athletes

\begin{tabular}{ccccccc}
\hline $\begin{array}{l}\text { PRED } \\
\text { ICTOR }\end{array}$ & $\begin{array}{l}\text { ODDS } \\
\text { RATIO }\end{array}$ & $\begin{array}{l}\mathbf{9 5 \%} \text { Cl } \\
\text { Upper }\end{array}$ & $\begin{array}{l}\mathbf{9 5 \%} \text { Cl } \\
\text { Lower }\end{array}$ & $\mathbf{p}$ & $\begin{array}{l}\mathbf{C h i}^{2} \\
\text { Walda }\end{array}$ & $\begin{array}{l}\mathbf{R}^{2} \\
\text { Nagelkerke }\end{array}$ \\
\hline $\begin{array}{l}\text { NORM BMD dis. } \\
\text { PBF }\end{array}$ & 0.468 & 0.179 & 1.223 & 0.121 & 2.399 & 0.341 \\
MBF & 1.850 & 0.647 & 5.287 & 0.251 & 1.319 & \\
LBM & 32.578 & 1.629 & 651.604 & 0.023 & 5.195 & \\
ICW & 0.011 & 0.000 & 0.672 & 0.031 & 4.627 & \\
ECW & 0.003 & 0.000 & 0.347 & 0.016 & 5.793 & \\
BMI & 1.408 & 0.915 & 2.167 & 0.119 & 2.428 & \\
NORM BMD prox. & & & & & \\
TBW & 0.250 & 0.046 & 1.372 & 0.111 & 2.546 & 0.177 \\
SLM & 5.008 & 1.289 & 19.453 & 0.020 & 5.415 & \\
ICW & 0.354 & 0.164 & 0.761 & 0.008 & 7.069 & \\
\hline
\end{tabular}

The original article can be found online at https://doi.org/10.1186/s11556021-00262-0

* Correspondence: karol.gryko@awf.edu.pl

${ }^{3}$ Department of Sport Games, Józef Piłsudski University of Physical Education in Warsaw, Marymoncka 34, 00-968 Warsaw, Poland

Full list of author information is available at the end of the article

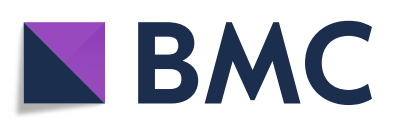

(c) The Author(s). 2021 Open Access This article is licensed under a Creative Commons Attribution 4.0 International License, which permits use, sharing, adaptation, distribution and reproduction in any medium or format, as long as you give appropriate credit to the original author(s) and the source, provide a link to the Creative Commons licence, and indicate if changes were made. The images or other third party material in this article are included in the article's Creative Commons licence, unless indicated otherwise in a credit line to the material. If material is not included in the article's Creative Commons licence and your intended use is not permitted by statutory regulation or exceeds the permitted use, you will need to obtain permission directly from the copyright holder. To view a copy of this licence, visit http://creativecommons.org/licenses/by/4.0/ The Creative Commons Public Domain Dedication waiver (http://creativecommons.org/publicdomain/zero/1.0/) applies to the data made available in this article, unless otherwise stated in a credit line to the data. 
Table 5 Multiple backward stepwise logistic regression in female masters athletes

\begin{tabular}{|c|c|c|c|c|c|c|}
\hline PREDICTOR & ODDS RATIO & 95\% Cl Upper & 95\% CI Lower & $\mathbf{p}$ & Chi $^{2}$ Walda & $R^{2}$ Nagelkerke \\
\hline \multicolumn{7}{|l|}{ NORM BMD dis. } \\
\hline ICW & 10.174 & 2.223 & 46.565 & 0.003 & 8.936 & 0.397 \\
\hline MBF & 0.734 & 0.532 & 1.012 & 0.059 & 3.566 & \\
\hline LBM & 0.470 & 0.249 & 0.888 & 0.020 & 5.418 & \\
\hline BMI & 1.515 & 0.883 & 2.601 & 0.132 & 2.274 & \\
\hline Speed-power athletes & 0.603 & 0.214 & 1.699 & 0.166 & 1.915 & \\
\hline Throws athletes & 2.204 & 0.222 & 21.879 & 0.349 & 0.876 & \\
\hline \multicolumn{7}{|l|}{ NORM BMD prox. } \\
\hline ICW & 5.254 & 1.099 & 25.112 & 0.038 & 4.320 & 0.389 \\
\hline LBM & 0.590 & 0.307 & 1.134 & 0.114 & 2.502 & \\
\hline Speed-power athletes & 1.859 & 0.389 & 8.878 & 0.099 & 2.729 & \\
\hline Endurance athletes & 0.585 & 0.102 & 3.365 & 0.186 & 1.749 & \\
\hline
\end{tabular}

\section{Author details}

'Department of Human Biology, Józef Piłsudski University of Physical

Education in Warsaw, Marymoncka 34, 00-968 Warsaw, Poland. ²Department of Theory of Sport, Józef Piłsudski University of Physical Education in Warsaw, Marymoncka 34, 00-968 Warsaw, Poland. ${ }^{3}$ Department of Sport Games, Józef Piłsudski University of Physical Education in Warsaw, Marymoncka 34, 00-968 Warsaw, Poland. ${ }^{4}$ Department of Team Sport Games, University School of Physical Education in Wrocław, Al. Ignacego Jana Paderewskiego 35, 51-612 Wrocław, Poland.

Published online: 03 July 2021

\section{Reference}

1. Kopiczko A, Adamczyk JG, Gryko K, Popowczak M. Bone mineral density in elite masters athletes: the effect of body composition and long-term exercise. Eur Rev Aging Phys Act. 2021). https://doi.org/10.1186/s11556-02100262-0;18(1):7. 